\title{
Clinical Significance of NADPH Oxidase 5 in Human Colon Cancer
}

\author{
NAOKI ASHIZAWA, HIROKI SHIMIZU, MAKOTO SUDO, SHINJI FURUYA, \\ HIDENORI AKAIKE, NAOHIRO HOSOMURA, YOSHIHIKO KAWAGUCHI, HIDETAKE AMEMIYA, \\ HIROMICHI KAWAIDA, SHINGO INOUE, HIROSHI KONO and DAISUKE ICHIKAWA
}

First Department of Surgery, Faculty of Medicine, University of Yamanashi, Yamanashi, Japan

\begin{abstract}
Background/Aim: Recent studies have reported the involvement of NADPH oxidases (NOXs) in tumor progression. However, the role of NOX5 in colon cancer is unclear. We examined the clinical significance of NOX5 expression in colon cancer. Patients and Methods: NOX5 expression was evaluated by immunohistochemistry in 119 patients with stage II or III colon cancer, and the relationship between NOX5 expression and clinicopathological data was analyzed. Results: Of all tissues, $39.5 \%$ were negative and $60.5 \%$ were positive for NOX5 expression. Positive expression was significantly associated with undifferentiated histology $(p=0.037)$ and lymph node metastasis $(p=0.023)$. The 5-year progression-free survival rate of NOX5-positive patients was significantly worse than that of NOX5-negative patients $(p=0.046)$. The rates of local recurrence observed in NOX5-positive patients were higher than that in NOX5negative patients. Conclusion: NOX5 expression may be related to poor prognostic factors and could be useful as a prognostic biomarker.
\end{abstract}

The NADPH oxidase (NOX) family comprises seven transmembrane proteins, NOX1 through NOX5 and DUOX1 and 2, which affect reactive oxygen species (ROS) generation by transporting electrons across biological membranes to transform oxygen into superoxide. ROS are oxygen-derived chemical compounds that have been implicated in many human diseases such as atherosclerosis, diabetes, neurodegeneration, aging, and cancer $(1,2)$. ROS can damage DNA, RNA, lipids, and proteins, leading to increased mutations and altered enzyme and protein functions. Thus, XROS contribute to the multistage carcinogenesis process via

Correspondence to: Hiroki Shimizu, MD, Ph.D., First Department of Surgery, Faculty of Medicine, University of Yamanashi, 1110 Shimokato, Chuo, Yamanashi 409-3898, Japan. Tel: +81 552737390, Fax: +81 552737390, e-mail: hrshimizu@yamanashi.ac.jp

Key Words: NADPH oxidase 5, colon cancer, immunohistochemistry. the induction of tumor growth by facilitating mutagenesis, tumor initiation, and tumor promotion $(3,4)$. Additionally, many studies have reported that ROS may regulate signaling pathways, including the platelet derived growth factor/ epidermal growth factor receptors, the JAK-STAT pathway, and the ERK-MAPK pathway (5-8).

NOXs are activated in chronic inflammatory diseases such as inflammatory bowel disease and pulmonary fibrosis ( 9 , 10). Further, NOXs are involved in the regulation of cell proliferation and tumorigenesis in various cancers, including colon, prostate, and pancreatic cancers (11-15). NOX1 expression is significantly higher in colon cancer tissues than in adjacent nonmalignant tissues. Recent studies have suggested that NOX1 plays a role in the regulation of colonic cell growth and apoptosis, tumor angiogenesis, and Ras oncogene transformation (16-18). Increased expression of NOX5 has been demonstrated in a number of cancers, including prostate cancer (19), malignant melanoma (20), Barrett's esophageal adenocarcinoma (21), breast cancer (22), and hairy cell leukemia (23). Previous research has suggested that NOX5 has a role in increasing proliferation, reducing apoptosis, and damaging DNA (24). According to a multi-tumor tissue microarray, NOX5 is highly expressed in colon cancer, as well as in melanoma, lymphoma, breast cancer, and prostate cancer (25). However, the significance of NOX5 expression in human colon cancer is still unclear. Therefore, in this study, we examined the levels of NOX5 expression via immunohistochemistry and investigated their association with the clinicopathological features and prognosis of human colon cancer.

\section{Patients and Methods}

Patients and clinical specimens. A total of 119 patients who underwent a curative operation for stage II or III colon cancer at the University of Yamanashi Hospital from January 2007 to December 2013 were enrolled in this study. The clinicopathological data of all patients were collected from hospital records and analyzed. Staging was based on the International Union Against Cancer/TNM classification of Malignant Tumors (8th edition) (26). The cecum/ 
ascending/transverse colon was defined as the right-sided colon and the descending/sigmoid colon was defined as the left-sided colon. Regarding the recurrence pattern, recurrences at the peritoneum and retroperitoneum were included as local recurrence. The median follow-up period was 1833 days (range $=1,507-, 2058$ days). This study was approved by the Ethics Committee of the University of Yamanashi Hospital (approval number of the institution: 1940), and written informed consent was obtained from all patients.

Immunohistochemistry staining analysis. Paraffin sections $(4-\mu \mathrm{m}$ thickness) of the tumor tissues were subjected to immunohistochemical staining for the NOX5 protein using the avidin-biotin complex method. Briefly, paraffin sections were dewaxed in xylene and dehydrated through a graded series of alcohols. Antigen retrieval was performed by heating samples in Dako Target Retrieval Solution (Agilent Technologies, Santa Clara, CA, USA) for $10 \mathrm{~min}$ at $98^{\circ} \mathrm{C}$. Endogenous peroxidases were suppressed by incubating the sections for $10 \mathrm{~min}$ in Dako REAL Peroxidase-Blocking Solution (Agilent). The signals caused by endogenous avidin and biotin were decreased by incubating the sections in Dako Biotin-Blocking System (Agilent). The sections were incubated in normal serum, and then incubated overnight at $4^{\circ} \mathrm{C}$ with NOX5 antibody (1:100; Biorbyt, Cambridge, UK), which was diluted in Dako Antibody Diluent with Background (Agilent). The avidin-biotin-peroxidase complex system (VECTASTAIN Elite ABC Rabbit IgG kit; Vector Laboratories, Burlingame, CA, USA) was used with diaminobenzene tetrahydrochloride for color development. The sections were counterstained with hematoxylin. Finally, the sections were dehydrated through a graded series of alcohols, cleared in xylene, and mounted.

Assessment of NOX5 expression levels. The levels of NOX5 expression in the immunohistochemically stained samples were graded according to the strongest staining intensity. Staining intensity was scored as 1 (weakly reactive), 2 (moderately reactive), and 3 (strongly reactive) (Figure 1A-C). Samples with a score of 1 were defined as negative for NOX5 expression, and those with a score of 2 or 3 were defined as positive for NOX 5 expression.

Statistical analysis. The data were analyzed using JMP statistical software (version 14.2; SAS Institute, Cary, NC, USA). The chi-square test or Fisher's exact test were used to assess differences between proportions, and Student's $t$-test was used to assess continuous variables. The Kaplan-Meier method was utilized to calculate survival curves, and differences in survival were evaluated using the log-rank test. The Cox proportional hazards regression model was applied to analyze the independent prognostic factors, and a $p$-value less than 0.05 was considered to indicate statistical significance.

\section{Results}

The immunohistochemistry staining for NOX5 revealed that the number of tumor tissues with scores of 1,2 , and 3 were $47(39.5 \%), 55(46.2 \%)$, and $17(14.3 \%)$, respectively. Of the 119 patients, $72(60.5 \%)$ were NOX5 positive (score of 2 or 3 ), and a strong staining pattern of NOX5 was particularly observed around areas of mucus (Figure 1D).

Table I shows that female sex $(p=0.014)$, poorer differentiated histology $(p=0.037)$, and lymph node metastasis $(p=0.023)$ are significantly associated with
Table I. Correlation between clinicopathological features and NOX5 expression in 119 colon cancer patients.

\begin{tabular}{|c|c|c|c|}
\hline \multirow[b]{2}{*}{ Variable } & \multicolumn{2}{|c|}{ NOX5 expression } & \multirow[b]{2}{*}{$p$-Value } \\
\hline & $\begin{array}{l}\text { Negative } \\
(n=47)\end{array}$ & $\begin{array}{c}\text { Positive } \\
(n=72)\end{array}$ & \\
\hline \multicolumn{4}{|l|}{ Gender } \\
\hline Male & $32(68.1)$ & $32(44.4)$ & \multirow[t]{2}{*}{0.014} \\
\hline Female & $15(31.9)$ & $40(55.6)$ & \\
\hline \multicolumn{4}{|l|}{ Age, years } \\
\hline $67.1 \pm 17.2$ & $67.4 \pm 15.1$ & 0.927 & \\
\hline \multicolumn{4}{|c|}{ Location of the tumor } \\
\hline Cecum & $15(31.9)$ & $19(26.4)$ & \multirow[t]{5}{*}{0.455} \\
\hline Ascending & $3(6.4)$ & $13(18.0)$ & \\
\hline Transverse & $2(4.3)$ & $2(2.8)$ & \\
\hline Descending & $19(40.4)$ & $26(36.1)$ & \\
\hline Sigmoid & $8(17.0)$ & $12(16.7)$ & \\
\hline Tumor size, mm & $52.8 \pm 20.8$ & $48.5 \pm 19.2$ & 0.251 \\
\hline \multicolumn{4}{|l|}{ Histological type } \\
\hline Differentiated & $42(89.3)$ & $52(72.2)$ & \multirow[t]{2}{*}{0.037} \\
\hline Undifferentiated & $5(10.6)$ & $20(27.7)$ & \\
\hline \multicolumn{4}{|l|}{ Depth of tumor } \\
\hline $\mathrm{T} 2$ & $1(2.0)$ & $2(2.7)$ & \multirow[t]{4}{*}{0.249} \\
\hline $\mathrm{T} 3$ & $33(70.2)$ & $50(69.4)$ & \\
\hline $\mathrm{T} 4 \mathrm{a}$ & $6(12.7)$ & $16(22.2)$ & \\
\hline $\mathrm{T} 4 \mathrm{~b}$ & $7(14.8)$ & $4(5.5)$ & \\
\hline \multicolumn{4}{|c|}{ Lymph node metastasis } \\
\hline Negative & $33(70.2)$ & $35(48.6)$ & \multirow[t]{2}{*}{0.023} \\
\hline Positive & $14(29.7)$ & $37(51.3)$ & \\
\hline \multicolumn{4}{|l|}{ Lymphatic invasion } \\
\hline Negative & $15(31.9)$ & $23(31.9)$ & \multirow[t]{2}{*}{1} \\
\hline Positive & $32(68.1)$ & $49(68.1)$ & \\
\hline \multicolumn{4}{|l|}{ Venous invasion } \\
\hline Negative & $14(29.8)$ & $23(31.9)$ & \multirow[t]{2}{*}{0.842} \\
\hline Positive & $33(70.2)$ & $49(68.1)$ & \\
\hline \multicolumn{4}{|c|}{ Adjuvant chemotherapy } \\
\hline Negative & $15(31.9)$ & $25(34.7)$ & \multirow[t]{2}{*}{0.844} \\
\hline Positive & $32(68.1)$ & $47(65.2)$ & \\
\hline
\end{tabular}

Values are $\mathrm{n}(\%)$ or mean \pm SD unless otherwise indicated.

positive NOX5 expression. However, tumor location, tumor depth, and lymphovascular invasion are not significantly correlated with the expression levels of NOX5.

We also assessed whether NOX5 expression is a prognostic factor for human colon cancer. The 5-year progression-free survival (PFS) rate of the NOX5-positive group $(71.1 \%)$ was significantly lower than that of the NOX5-negative group (88.9\%) $(p=0.046)$ (Figure 2). Specifically, the 5-year PFS of patients with scores of 1,2, and 3 were $88.9 \%, 73.2 \%$, and $62.2 \%$, respectively. The 5year PFS rate of the three groups appeared to be related to NOX5 intensity, and a significant difference was found between patients with scores of 1 and $3(p=0.032)$ (Figure 3 ). Conversely, the 5-year disease-specific survival rates of the NOX5-negative (88.7\%) and NOX5-positive (90.5\%) 

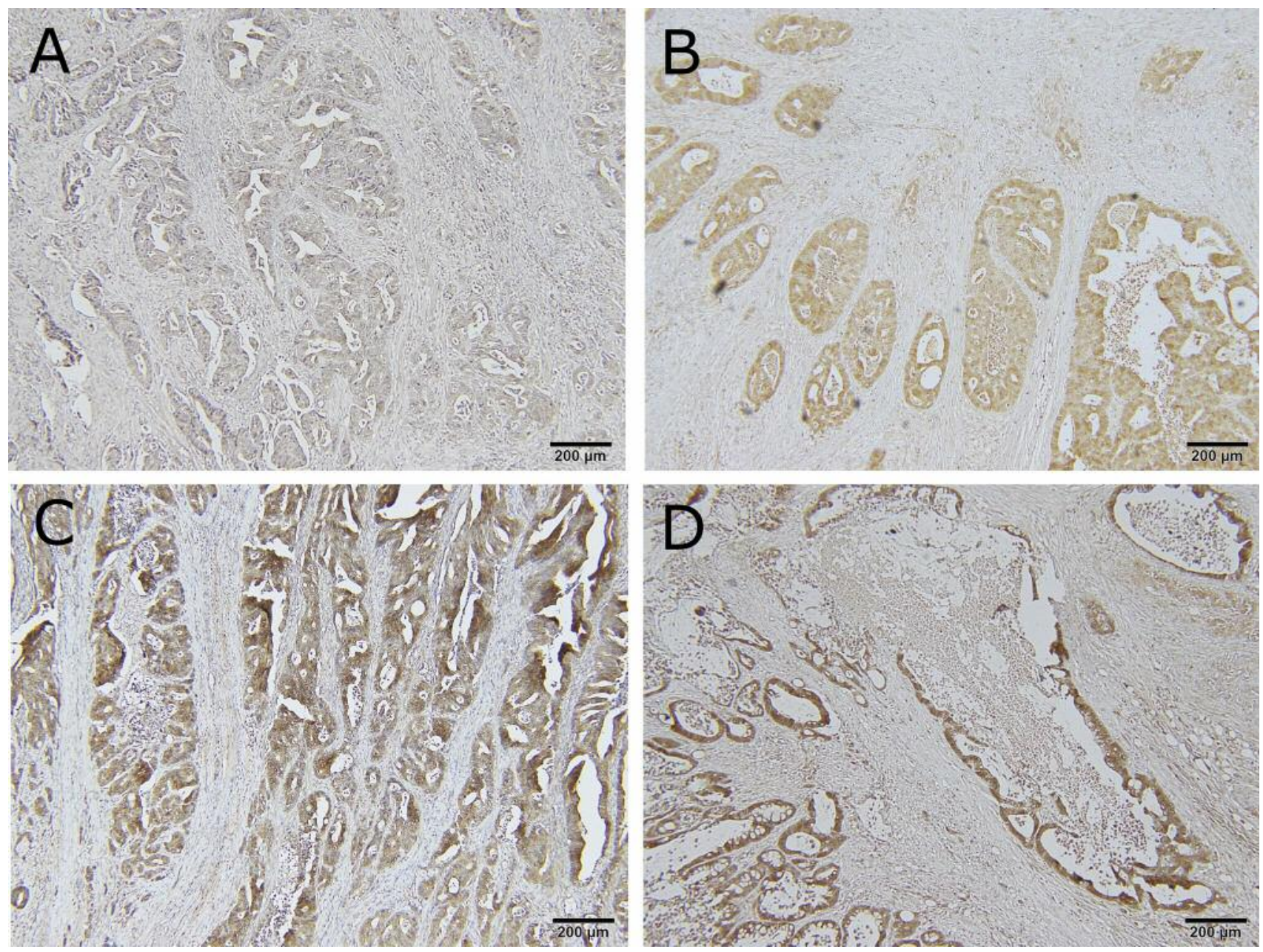

Figure 1. Immunohistochemical staining of primary human colon cancer samples with NOX5 antibody. A: Score 1. B: Score 2. C: Score 3. D: Strong expression around muсus.

groups did not significantly differ $(p=0.832)$. The univariate analysis showed that the presence of deeper tumor invasion ( $p=0.001)$, lymph node metastasis $(p=0.001)$, and venous invasion $(p=0.033)$ were also correlated with a poorer 5 -year PFS (Table II). Further, the multivariate analysis showed that the presence of deeper tumor invasion (hazard ratio $[\mathrm{HR}]=3.740, p=0.002)$, lymph node metastasis $(\mathrm{HR}=3.142$, $p=0.016)$, and venous invasion $(\mathrm{HR}=4.321, p=0.019)$ were independent prognostic factors (Table III). NOX5 expression levels were not selected as an independent prognostic factor (HR=2.021, $p=0.188$ ).

The number of patients with an initial recurrence at local, distant, and both sites were 0, $5(100 \%)$, and 0 in the NOX5negative group and $5(26.3 \%), 13(68.4 \%)$, and $1(5.3 \%)$ in the NOX5-positive group, respectively. No significant difference was found between the groups in terms of the recurrence pattern $(p=0.640)$.

\section{Discussion}

In the present study, we examined the clinical significance of NOX5 expression in human colon cancer tissue by immunohistochemical staining. To our knowledge, this is the first report to describe the relationship between NOX5 expression and clinicopathological features, including patients' prognosis, in locally advanced colon cancer patients.

The NOX family comprises seven members, and many studies have reported that NOX family members modulate ROS generation and consequently promote tumorigenesis by activating cell signaling in various cancers $(11,14,21,24$, $27,28)$. Several studies on colon cancer have reported that NOX1 is highly expressed in colon cancer tissue and promotes colon cancer cell growth, migration, invasion, and the activation of signaling pathways by modulating ROS generation $(10,12,13,29)$. Juhasz et al. reported that the 
Table II. Univariate analysis for prognostic factors associated with 5-year progression-free survival.

\begin{tabular}{|c|c|c|c|}
\hline Variable & $\begin{array}{c}\text { Number } \\
n=119\end{array}$ & $\begin{array}{c}5 \text {-year PFS }{ }^{\dagger} \\
\text { rate }(\%)\end{array}$ & $p$-Value \\
\hline \multicolumn{4}{|l|}{ Gender } \\
\hline Male & 64 & 75.2 & \multirow[t]{2}{*}{0.298} \\
\hline Female & 55 & 81.7 & \\
\hline \multicolumn{4}{|l|}{ Age, years } \\
\hline$<70$ & 55 & 75.5 & \multirow[t]{2}{*}{0.537} \\
\hline $70 \leq$ & 64 & 80.8 & \\
\hline \multicolumn{4}{|l|}{ Location } \\
\hline Right side & 70 & 83.1 & \multirow[t]{2}{*}{0.244} \\
\hline Left side & 49 & 71.9 & \\
\hline \multicolumn{4}{|l|}{ Tumor size, mm } \\
\hline$<50$ & 58 & 79.4 & \multirow[t]{2}{*}{0.772} \\
\hline$\geq 50$ & 61 & 77.2 & \\
\hline \multicolumn{4}{|l|}{ Histological type } \\
\hline Differentiated & 94 & 77.4 & \multirow[t]{2}{*}{0.606} \\
\hline Undifferentiated & 25 & 81.8 & \\
\hline \multicolumn{4}{|l|}{ Depth of tumor } \\
\hline $\mathrm{T} 2, \mathrm{~T} 3$ & 86 & 85.3 & \multirow[t]{2}{*}{0.001} \\
\hline $\mathrm{T} 4$ & 33 & 58.2 & \\
\hline \multicolumn{4}{|c|}{ Lymph node metastasis } \\
\hline Negative & 68 & 88.9 & \multirow[t]{2}{*}{0.001} \\
\hline Positive & 51 & 64.0 & \\
\hline \multicolumn{4}{|l|}{ Lymphatic invasion } \\
\hline Negative & 38 & 85.7 & \multirow[t]{2}{*}{0.200} \\
\hline Positive & 81 & 74.9 & \\
\hline \multicolumn{4}{|l|}{ Venous invasion } \\
\hline Negative & 37 & 90.9 & \multirow[t]{2}{*}{0.033} \\
\hline Positive & 82 & 72.8 & \\
\hline \multicolumn{4}{|c|}{ Adjuvant chemotherapy } \\
\hline Negative & 40 & 74.5 & \multirow[t]{2}{*}{0.537} \\
\hline Positive & 79 & 80.3 & \\
\hline \multicolumn{4}{|l|}{ NOX5末 expression } \\
\hline Negative & 47 & 88.9 & \multirow[t]{2}{*}{0.046} \\
\hline Positive & 72 & 71.1 & \\
\hline
\end{tabular}

$\dagger$ PFS: Progression-free survival; ${ }^{\ddagger}$ NOX5: NADPH oxidases 5.

depletion of NOX1 expression resulted in decreased tumor growth, blood vessel density, and hypoxia-inducible factor $1 \alpha$ expression in a colon cancer xenograft model (12).

NOX5 was the last to be identified in the NOX family and is unique because it is regulated by $\mathrm{Ca}^{2+}$; its hyperactivation has been observed in cardiovascular and kidney diseases (30). Additionally, unlike NOX1 through NOX4, which are primarily located in cell membranes, NOX5 moves from perinuclear and endoplasmic reticulum regions to cell membranes upon activation by $\mathrm{Ca}^{2+}$, growth factors, vasoactive agents, and cytokines (30). Antony et al. examined a multi-tumor tissue microarray for NOX5 and reported that the expression levels of NOX5 were elevated in tumor tissues of various organs, including the prostate (NOX5 positive in $81 \%$ ), ovary $(70 \%)$, breast $(61 \%)$, colon

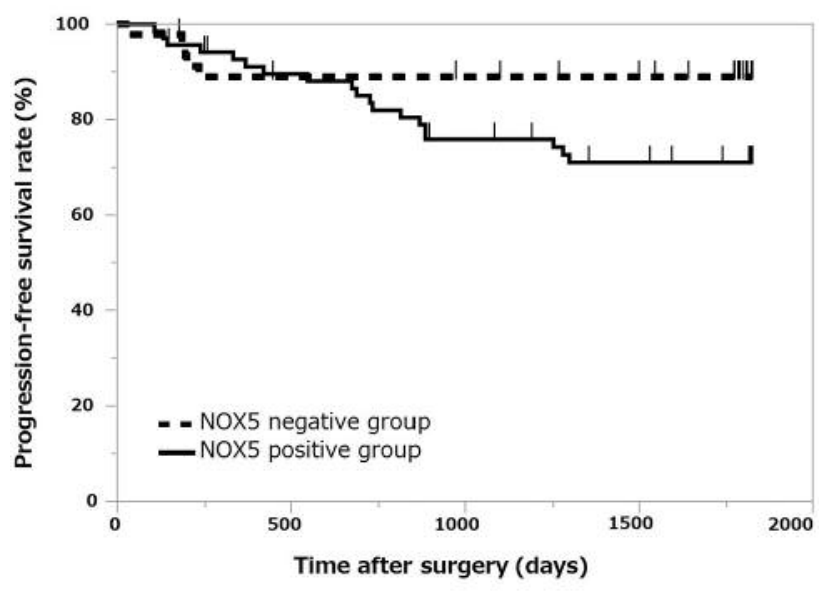

Figure 2. The 5-year progression-free survival rates were $88.9 \%$ and $71.1 \%$ in the NOX5-negative and NOX5-positive groups, respectively $(p=0.046)$.

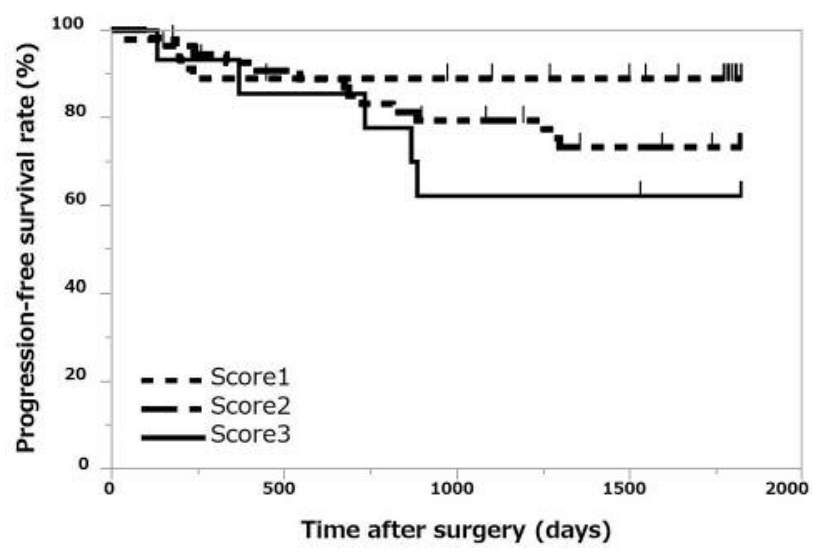

Figure 3. The 5-year progression-free survival rates were $88.9 \%, 73.2 \%$, and $62.2 \%$ in the Score 1,2, and 3 groups, respectively. The p-values were 0.083 (Score 1 vs. 2), 0.046 (Score 1 vs. 3), and 0.428 (Score 2 vs. 3).

Table III. Multivariate analysis for prognostic factors associated with 5-year progression-free survival.

\begin{tabular}{lccc}
\hline Variable & $\mathrm{OR}^{\dagger}$ & $95 \% \mathrm{CI}^{\ddagger}$ & $p$-Value \\
\hline $\begin{array}{l}\text { Depth of tumor } \\
\quad \text { T2, T3 versus } \mathrm{T} 4\end{array}$ & 3.740 & $1.641-8.523$ & 0.002 \\
$\quad \begin{array}{l}\text { Lymph node metastasis } \\
\quad \text { Negative versus } \text { positive }\end{array}$ & 3.142 & $1.238-7.964$ & 0.016 \\
$\quad \begin{array}{l}\text { Venous invasion } \\
\quad \text { Negative versus } \text { positive }\end{array}$ & 4.321 & $1.276-14.770$ & 0.019 \\
$\quad \begin{array}{l}\text { NOX5 expression } \\
\quad \text { Negative } \text { versus } \text { positive }\end{array}$ & 2.021 & $0.709-5.757$ & 0.188 \\
\hline
\end{tabular}

$\dagger$ OR: Odds ratio; $¥$ CI: confidence interval. 
(60\%), and lung (56\%) (25). However, the significance of NOX5 expression in human colon cancer is still unclear.

To our knowledge, this is the first study to examine the expression levels of NOX5 by immunohistochemical staining of human colon cancer tissues to assess the relationship between NOX5 expression and patients' clinicopathological outcomes. Our data showed a positive NOX5 expression rate of $60.5 \%$, which is similar to the results of a previous study (60\%) (25). Further, NOX5-positive expression was significantly correlated with poorer differentiated histology $(p=0.037)$ (Table I), and NOX5 protein was strongly stained around areas of mucus in mucinous carcinomas (Figure 1D). Although Accetta et al. reported that NOX5-mediated ROS can induce differentiation of human oligodendrocytes (31), the relationship between NOX5 and cellular differentiation in cancer cells is unclear, and further research using an in vitro model are warranted.

The prognostic analyses revealed that the NOX5-positive group had a significantly worse 5-year PFS than the NOX5negative group $(p=0.046)$. Additionally, the 5 -year PFS of patients with scores of 1,2 , and 3 were related to the NOX5 intensity, as shown in Figure 3. These results suggest that NOX5 might play an oncogenic role in colon cancer. Several studies have shown that NOX5 is also correlated with tumorigenesis in several kinds of cancers, including prostate cancer, Barrett's esophageal adenocarcinoma, hairy cell leukemia, breast cancer, and malignant melanoma (14, 15, 20-24). Further, Höll et al. reported that NOX5-derived ROS modulates intracellular signaling cascades, including protein kinase $\mathrm{C}$ zeta and c-Jun $\mathrm{N}$ terminal kinase, and promotes proliferation and survival of prostate cancer cells (19). Dho et al. revealed that the expression of NOX5 long form (NOX5-L) is regulated by STAT5A, and that NOX5-L promotes proliferation and invasion in breast cancer cells (22). Moreover, in Barrett's esophagus, acid reflux increases NOX5 expression and ROS generation, which suggests that this increase in ROS generation might cause DNA damage, thereby contributing to the progression from Barrett's esophagus to esophageal adenocarcinoma $(21,24)$. However, no studies have clarified the oncogenic role of NOX5 in colon cancer; thus, further studies using molecular methods are warranted to clarify the role of NOX5 in the tumorigenesis of colon cancer.

Regarding the recurrence pattern, local recurrence was more common in NOX5-positive patients than in NOX5negative patients. However, the number of recurrent cases was very small, and further research using a larger cohort is needed to confirm these findings. Additionally, the role of NOX5 in cellular movement needs to be clarified.

In conclusion, we demonstrated that NOX5 expression is related to poor prognostic factors and worse prognosis in locally advanced colon cancer patients. NOX5 may be a useful biomarker of tumor prognosis after curative surgical resection and could be used as a novel therapeutic target in colon cancer patients.

\section{Conflicts of Interest}

The Authors declare no conflicts of interest regarding this study.

\section{Acknowledgements}

The Authors thank Dr. Kunio Mochizuki from the Department of Human Pathology, University of Yamanashi, for the cooperation in the pathological assessment of IHC results performed in this study.

\section{Authors' Contributions}

Naoki Ashizawa performed the majority of experiments and wrote the manuscript. Hiroki Shimizu designed the research and helped to draft the manuscript. All Authors reviewed the manuscript.

\section{References}

1 Beckman KB and Ames BN: The free radical theory of aging matures. Physiol Rev 78(2): 547-581, 1998. PMID: 9562038. DOI: $10.1152 /$ physrev.1998.78.2.547

2 Halliwell B: Free radicals, antioxidants, and human disease: Curiosity, cause, or consequence? Lancet 344(8924): 721-724, 1994. PMID: 7915779. DOI: 10.1016/s0140-6736(94)92211-x

3 Sablina AA, Budanov AV, Ilyinskaya GV, Agapova LS, Kravchenko JE and Chumakov PM: The antioxidant function of the p53 tumor suppressor. Nat Med 11(12): 1306-1313, 2005. PMID: 16286925. DOI: $10.1038 / \mathrm{nm} 1320$

4 Ohshima H, Tatemichi $\mathrm{M}$ and Sawa T: Chemical basis of inflammation-induced carcinogenesis. Arch Biochem Biophys 417(1): 3-11, 2003. PMID: 12921773.

5 Simon AR, Rai U, Fanburg BL and Cochran BH: Activation of the jak-stat pathway by reactive oxygen species. Am J Physiol 275(6): C1640-1652, 1998. PMID: 9843726. DOI: 10.1152/ ajpcell.1998.275.6.C1640

6 Page K, Li J, Hodge JA, Liu PT, Vanden Hoek TL, Becker LB, Pestell RG, Rosner MR and Hershenson MB: Characterization of a rac1 signaling pathway to cyclin d (1) expression in airway smooth muscle cells. J Biol Chem 274(31): 22065-22071, 1999. PMID: 10419534. DOI: 10.1074/jbc.274.31.22065

7 Goldkorn T, Balaban N, Matsukuma K, Chea V, Gould R, Last J, Chan $\mathrm{C}$ and Chavez C: Egf-receptor phosphorylation and signaling are targeted by h2o2 redox stress. Am J Respir Cell Mol Biol 19(5): 786-798, 1998. PMID: 9806743. DOI: 10.1165/ ajrcmb.19.5.3249

8 González-Rubio M, Voit S, Rodríguez-Puyol D, Weber M and Marx M: Oxidative stress induces tyrosine phosphorylation of pdgf $\alpha$-and $\beta$-receptors and pp60c-src in mesangial cells. Kidney Int 50(1): 164-173, 1996. PMID: 8807585.

9 Ward PA and Hunninghake GW: Lung inflammation and fibrosis. Am J Respir Crit Care Med 157(4 Pt 2): S123-129, 1998. PMID: 9563771. DOI: 10.1164/ajrccm.157.4.nhlbi-10

10 Makhezer N, Ben Khemis M, Liu D, Khichane Y, Marzaioli V, Tlili A, Mojallali M, Pintard C, Letteron P, Hurtado-Nedelec M, El-Benna J, Marie JC, Sannier A, Pelletier AL and Dang PMC: Nox1-derived ros drive the expression of lipocalin-2 in colonic epithelial cells in inflammatory conditions. Mucosal Immunol 12(1): 117-131, 2019. PMID: 30279516. DOI: 10.1038/s41385018-0086-4 
11 Mochizuki T, Furuta S, Mitsushita J, Shang WH, Ito M, Yokoo Y, Yamaura M, Ishizone S, Nakayama J, Konagai A, Hirose K, Kiyosawa $\mathrm{K}$ and Kamata $\mathrm{T}$ : Inhibition of nadph oxidase 4 activates apoptosis via the akt/apoptosis signal-regulating kinase 1 pathway in pancreatic cancer panc-1 cells. Oncogene 25(26): 3699-3707, 2006. PMID: 16532036. DOI: 10.1038/ sj.onc. 1209406

12 Juhasz A, Markel S, Gaur S, Liu H, Lu J, Jiang G, Wu X, Antony S, Wu Y, Melillo G, Meitzler JL, Haines DC, Butcher D, Roy $\mathrm{K}$ and Doroshow JH: Nadph oxidase 1 supports proliferation of colon cancer cells by modulating reactive oxygen species-dependent signal transduction. J Biol Chem 292(19): 7866-7887, 2017. PMID: 28330872. DOI: 10.1074/jbc. M116.768283

13 Wang HP, Wang X, Gong LF, Chen WJ, Hao Z, Feng SW, Wu YB, Ye T and Cai YK: Nox1 promotes colon cancer cell metastasis via activation of the adam17 pathway. Eur Rev Med Pharmacol Sci 20(21): 4474-4481, 2016. PMID: 27874952

14 Brar SS, Corbin Z, Kennedy TP, Hemendinger R, Thornton L, Bommarius B, Arnold RS, Whorton AR, Sturrock AB, Huecksteadt TP, Quinn MT, Krenitsky K, Ardie KG, Lambeth JD and Hoidal JR: Nox5 nad(p)h oxidase regulates growth and apoptosis in du 145 prostate cancer cells. Am J Physiol Cell Physiol 285(2): C353-369, 2003. PMID: 12686516. DOI: 10.1152/ajpcell.00525.2002

15 Kumar B, Koul S, Khandrika L, Meacham RB and Koul HK: Oxidative stress is inherent in prostate cancer cells and is required for aggressive phenotype. Cancer Res 68(6): 1777-1785, 2008. PMID: 18339858. DOI: 10.1158/0008-5472.CAN-07-5259

16 Teshima S, Kutsumi H, Kawahara T, Kishi K and Rokutan K: Regulation of growth and apoptosis of cultured guinea pig gastric mucosal cells by mitogenic oxidase 1. Am J Physiol Gastrointest Liver Physiol 279(6): G1169-1176, 2000. PMID: 11093939. DOI: 10.1152/ajpgi.2000.279.6.G1169

17 Mitsushita J, Lambeth JD and Kamata T: The superoxidegenerating oxidase nox 1 is functionally required for ras oncogene transformation. Cancer Res 64(10): 3580-3585, 2004. PMID: 15150115. DOI: 10.1158/0008-5472.CAN-03-3909

18 Garrido-Urbani S, Jemelin S, Deffert C, Carnesecchi S, Basset O, Szyndralewiez C, Heitz F, Page P, Montet X, Michalik L, Arbiser J, Ruegg C, Krause KH and Imhof BA: Targeting vascular nadph oxidase 1 blocks tumor angiogenesis through a pparalpha mediated mechanism. PLoS One 6(2): e14665, 2011. PMID: 21326871. DOI: 10.1371/journal.pone.0014665

19 Holl M, Koziel R, Schafer G, Pircher H, Pauck A, Hermann M, Klocker H, Jansen-Durr P and Sampson N: Ros signaling by nadph oxidase 5 modulates the proliferation and survival of prostate carcinoma cells. Mol Carcinog 55(1): 27-39, 2016. PMID: 25559363. DOI: $10.1002 / \mathrm{mc} .22255$

20 Antony S, Jiang G, Wu Y, Meitzler JL, Makhlouf HR, Haines DC, Butcher D, Hoon DS, Ji J, Zhang Y, Juhasz A, Lu J, Liu H, Dahan I, Konate M, Roy KK and Doroshow JH: Nadph oxidase 5 (nox5)-induced reactive oxygen signaling modulates normoxic hif-1alpha and p27 (kip1) expression in malignant melanoma and other human tumors. Mol Carcinog 56(12): 2643-2662, 2017. PMID: 28762556. DOI: $10.1002 / \mathrm{mc} .22708$

21 Hong J, Li D and Cao W: Rho kinase rock2 mediates acidinduced nadph oxidase nox 5-s expression in human esophageal adenocarcinoma cells. PLoS One 11(2): e0149735, 2016. PMID: 26901778. DOI:10.1371/journal.pone. 0149735
22 Dho SH, Kim JY, Lee KP, Kwon ES, Lim JC, Kim CJ, Jeong D and Kwon KS: Stat5a-mediated nox5-1 expression promotes the proliferation and metastasis of breast cancer cells. Exp Cell Res 351(1): 51-58, 2017. PMID: 28034671. DOI: 10.1016/j.yexcr. 2016.12.020

23 Kamiguti AS, Serrander L, Lin K, Harris RJ, Cawley JC, Allsup DJ, Slupsky JR, Krause KH and Zuzel M: Expression and activity of nox 5 in the circulating malignant $\mathrm{b}$ cells of hairy cell leukemia. J Immunol 175(12): 8424-8430, 2005. PMID: 16339585. DOI: 10.4049 /jimmunol.175.12.8424

$24 \mathrm{Li} \mathrm{D}$ and Cao W: Role of intracellular calcium and nadph oxidase nox5-s in acid-induced DNA damage in barrett's cells and barrett's esophageal adenocarcinoma cells. Am J Physiol Gastrointest Liver Physiol 306(10): G863-872, 2014. PMID: 24699332. DOI: 10.1152/ajpgi.00321.2013

25 Antony S, Wu Y, Hewitt SM, Anver MR, Butcher D, Jiang G, Meitzler JL, Liu H, Juhasz A, Lu J, Roy KK and Doroshow JH: Characterization of nadph oxidase 5 expression in human tumors and tumor cell lines with a novel mouse monoclonal antibody. Free Radic Biol Med 65: 497-508, 2013. PMID: 23851018. DOI: $10.1016 / j$.freeradbiomed.2013.07.005

26 James D, Mark K, Christian W. TNM Classification of Malignant Tumors, 8th edition. Wiley-Blackwell: 73-76, 2017.

27 Kamata T: Roles of nox 1 and other nox isoforms in cancer development. Cancer Sci 100(8): 1382-1388, 2009. PMID: 19493276. DOI: 10.1111/j.1349-7006.2009.01207.x

28 Luxen S, Belinsky SA and Knaus UG: Silencing of duox nadph oxidases by promoter hypermethylation in lung cancer. Cancer Res 68(4): 1037-1045, 2008. PMID: 18281478. DOI: 10.1158/0008-5472.CAN-07-5782

29 Laurent E, McCoy JW, 3rd, Macina RA, Liu W, Cheng G, Robine S, Papkoff $\mathrm{J}$ and Lambeth JD: Nox 1 is over-expressed in human colon cancers and correlates with activating mutations in k-ras. Int J Cancer 123(1): 100-107, 2008. PMID: 18398843. DOI: $10.1002 / \mathrm{ijc} .23423$

30 Touyz RM, Anagnostopoulou A, Rios F, Montezano AC and Camargo LL: Nox5: Molecular biology and pathophysiology. Exp Physiol 104(5): 605-616, 2019. PMID: 30801870. DOI: 10.1113/EP086204

31 Accetta R, Damiano S, Morano A, Mondola P, Paterno R, Avvedimento EV and Santillo M: Reactive oxygen species derived from nox 3 and nox 5 drive differentiation of human oligodendrocytes. Front Cell Neurosci 10: 1-17, 2016. PMID: 27313511. DOI: $10.3389 /$ fncel.2016.00146 